\title{
BIOGENIC AMINES IN SMEAR RIPENED CHEESES
}

\author{
Olga Cwiková, Gabriela Franke
}

\begin{abstract}
Cheeses belong to high protein foods in which enzymatic and microbial activities form amino acids, which are then converted into biogenic amines (BAs) by the activity of bacterial decarboxylases. The most important conditions for BA formation include the presence of microorganisms, the availability of substrate, temperature and storage period, water activity, salt concentration, and the hygiene of the manufacturing process. Tyramine, histamine, 2-phenylethylamine, tryptamine, cadaverine, putrescine, spermidine and spermine were detected in smear ripened cheeses stored in different temperature regimes. The highest $(p<0.05)$ total BA content was found when storing the cheeses at the end of BBD (best before date) after 35 days in storage regime (A) or (C). During storage in regime (B), the total BA content $(p<0.05)$ after 49 days of storage was higher than on the production date $(B / 0)$. During storage, the tyramine content in regime (B) did not change $(p>0.05)$, while in the temperature regimes $(\mathrm{A})$ and $(\mathrm{C})$, the highest levels of tyramine and putrescine content were recorded in cheeses at the end of BBD after 35 days ripening. The content of polyamines in cheeses was higher $(p<0.05)$ at the end of storage than at the beginning, in all temperature regimes.
\end{abstract}

Keywords: biogenic amines; polyamines; smear ripened cheese;storage temperature and period

\section{INTRODUCTION}

Cheeses are food that is often associated with the content of biogenic amines (Bas) (Poveda, Molina and GómezAlonso, 2016). During ripening, substantial changes in the composition of cheeses take place (Pinho et al., 2004). Protein degradation leads to accumulation of free amino acids, which are then converted into BAs by bacterial decarboxylases (Komprda et al., 2007). Contaminant microorganisms such as enterococci, Enterobacteriaceae and lactic acid bacteria, such as lactobacilli (Madejska, Michalski and Osek, 2017), contribute to the formation of BA.

Among the most important BAs found in foods are tyramine, histamine, cadaverine, 2-phenylethylamine, tryptamine, putrescine, spermine, and spermidine (Önal, Tekkeli and Önal, 2013). Smear ripened cheeses have a higher BA content compared with other types of cheeses, which is related to the high protein content, extensive proteolysis, and highly active microbes with decarboxylase activity (Samková, Dadáková and Pelikánová, 2013; Torracca et al., 2016).

Typically, these cheeses contain up to hundreds mg. $\mathrm{kg}^{-1}$ of histamine, tyramine, putrescine, and cadaverine, up to tens $\mathrm{mg} \cdot \mathrm{kg}^{-1}$ of 2-phenylethylamine as well as minor content of tryptamine (Standarová et al., 2010). Cheeses also contain polyamines (Pas), such as agmatine, spermidine, and spermine (Novella-Rodríguez et al., 2003).
The aim of this paper was to find out if the storage temperature and period could affect the BA content in smear ripened cheeses.

\section{Scientific hypothesis}

The formation of BAs in cheeses is affected by the storage temperature - the higher the temperature, the higher the BA content.

The length of storage of cheeses affects their safety in terms of high BA content.

\section{MATERIAL AND METHODOLOGY}

The cheese for testing was delivered as small rounds (diameter $45 \mathrm{~mm}$, height $10 \mathrm{~mm}$ ), where a $100 \mathrm{~g}$ package contained 5 pieces of these round portions. Prior to shipment, the cheeses ripened for 7 days, while the best before date (BBD) on the package was 28 days. A total of 5 batches of the product were analysed.

The samples were divided into three groups designated as (A), (B), and (C) and stored in different temperature regimes. Sampling and subsequent analyses were performed on the day of manufacture $(\mathrm{A} / 0=\mathrm{B} / 0=\mathrm{C} / 0)$, at the end of $\mathrm{BBD}(\mathrm{A} / 35, \mathrm{~B} / 35, \mathrm{C} / 35)$, two weeks after $\mathrm{BBD}$ (A/49, B/49), and eight weeks after BBD (C/91).

Samples in the temperature regime (A) were stored at $6{ }^{\circ} \mathrm{C}$ after production for the entire BBD (7 days before and 28 days after shipment), i.e. 35 days. These cheeses 
were then stored for 14 days after the BBD expired at $6{ }^{\circ} \mathrm{C}$, i.e. 49 days in total $\left(6^{\circ} \mathrm{C} / 35\right.$ days $\rightarrow 6{ }^{\circ} \mathrm{C} / 14$ days $)$. Samples in the temperature regime (B) were stored at $6^{\circ} \mathrm{C}$ after production for 28 days ( 7 days before and 21 days after shipment), i.e. 28 days, then they were frozen and stored at $-18{ }^{\circ} \mathrm{C}$ for 7 days. Subsequently, after BBD (35 days), the cheeses were stored at $6{ }^{\circ} \mathrm{C}$ for 14 days, i.e. 49 days in total $\left(6{ }^{\circ} \mathrm{C} / 28\right.$ days $\rightarrow-18{ }^{\circ} \mathrm{C} / 7$ days $\rightarrow$ $6{ }^{\circ} \mathrm{C} / 14$ days). Samples in the temperature regime (C) were stored at $6{ }^{\circ} \mathrm{C}$ after production for the entire BBD (7 days before and 28 days after shipment), i.e. 35 days. They were then frozen and stored for 49 days (7 weeks) at $-18{ }^{\circ} \mathrm{C}$. After 49 days of freezing, the cheeses were stored at $6{ }^{\circ} \mathrm{C}$ for 7 days, i.e. 91 days in total $\left(6{ }^{\circ} \mathrm{C} / 35\right.$ days $\rightarrow$ $-18^{\circ} \mathrm{C} / 49$ days $\rightarrow 6{ }^{\circ} \mathrm{C} / 7$ days).

The analyses were carried out in the laboratory of the Institute of Food Technology, Faculty of AgriSciences of Mendel University in Brno.

BA Assay: A cheese sample was grated to a particle size of about $3 \mathrm{~mm}$ and $10 \mathrm{~g}$ was weighed into an $85 \mathrm{~mL}$ plastic centrifuge tube. After addition of $20 \mathrm{~mL}$ of $0.1 \mathrm{M}$ $\mathrm{HCl}$ and $0.5 \mathrm{~mL}$ solution of internal standard (1,7-diaminoheptane) with concentration of $1 \mathrm{mg} \cdot \mathrm{mL}^{-1}$, the sample was extracted with a disintegrant for 2 minutes. The suspension was centrifuged at $755 \mathrm{~g}$ for 10 minutes at $4{ }^{\circ} \mathrm{C}$ in order to separate the solid and fat. The supernatant was filtered and the solid was re-extracted by the same procedure. The combined extracts were added up to $50 \mathrm{~mL}$ with deionized water and filtered through a nylon membrane filter. The BA derivatization was carried out with dansyl chloride, where $1 \mathrm{~mL}$ of extract or standard was mixed with $0.5 \mathrm{~mL}$ of saturated $\mathrm{Na}_{2} \mathrm{CO}_{3}$ (pH adjusted to 11.2 ). In a $4 \mathrm{~mL}$ sample vial, $1 \mathrm{~mL}$ of derivatizing agent ( $5 \mathrm{mg}$ of dansyl chloride in $1 \mathrm{~mL}$ of acetone) was added and stirred for 1 minute on an agitator. Derivatization was carried out for 1 hour at $40{ }^{\circ} \mathrm{C}$ without light access with occasional shaking at 15 minutes intervals. After derivatization, $250 \mu \mathrm{L}$ of $10 \mathrm{mM}$ ammonia was added to remove unreacted dansyl chloride and again stirred for 1 minute on the agitator. Ammonia reacted with excess dansyl chloride and the resulting reaction product was eluted before BA. Containers with dansyl chloride acetone solution and all standards and extracts were immediately after adding packaged in aluminium foil because of their photolability. After a 30-minute reaction, the hydrophobic amine derivatives were extracted with diethyl ether $(3 \times 1 \mathrm{~mL})$ while the hydrophilic amino acid derivatives remained in the aqueous phase. The organic phase was evaporated to dry state with a stream of nitrogen and the evaporation residue was dissolved in $0.5 \mathrm{~mL} \mathrm{ACN}$ or in $1 \mathrm{~mL} \mathrm{ACN} \mathrm{(standard)} \mathrm{and} \mathrm{the} \mathrm{solution} \mathrm{was} \mathrm{again} \mathrm{filtered}$ through a $0.45 \mu \mathrm{m}$ nylon membrane filter and dosed on a chromatographic column. The amount of the injected real sample was modified as needed, in the case of standard it was $10 \mu \mathrm{L}$.

Biogenic amines were separated on a Zorbax Eclipse XDB C18 column (150 mm x $4.6 \mathrm{~mm}$, particle size $5 \mu \mathrm{m})$ with Meta Guard ODS 2 pre-column $(30 \mathrm{~mm}$ x $4.6 \mathrm{~mm}$, particle size $5 \mu \mathrm{m}$ ) at a flow rate of $0.8 \mathrm{~mL} \cdot \mathrm{min}^{-1}$ using the HP 1100 Chromatograph. Separation after derivatization with dansyl chloride was carried out by gradient elution with $\mathrm{H}_{2} \mathrm{O} / \mathrm{ACN}$ (time $0-23$ minutes: $\mathrm{H}_{2} \mathrm{O} 35-0 \%$, ACN $65-100 \%$ ) followed by detection with a photometric
UV/VIS detector at $254 \mathrm{~nm}$. To identify the separated substances in the samples, a comparison of the retention times of the standards and the substances present in the sample was used. During the analysis, the UV spectra of the eluates were captured at peak and then compared with the spectra of the standard substances, and the identity of the substances was confirmed or refuted on the basis of the so-called identity factor.

All BA standards were supplied as hydrochlorides and their concentrations after derivatization with dansyl chloride were expressed in mg. $\mathrm{kg}^{-1}$ of the original (fresh) sample (not per kg of dry weight) to better express the conditions at consumption. The BA concentration in a sample was corrected by the internal standard method. The internal standard was prepared by dissolving $100 \mathrm{mg}$ of 1,7-diaminoheptane in $100 \mathrm{~mL}$ deionized water (concentration $1 \mathrm{mg} \cdot \mathrm{mL}^{-1}$ ).

The BA/PA standards stock solution was prepared as a mixed standard for all amines to be analyses (tryptamine, 2-phenylethylamine, putrescine, cadaverine, histamine, tyramine, spermidine, and spermine) by dissolving $100 \mathrm{mg}$ of each of the amines (in the form of hydrochloride) in $100 \mathrm{~mL}$ of deionized water (standard concentration of each amine $1 \mathrm{mg} \cdot \mathrm{mL}^{-1}$ ). The BA/PA standard working solution was obtained by mixing $0.5 \mathrm{~mL}$ BA/PA standard stock solution with $0.5 \mathrm{~mL}$ internal standard solution and subsequent treatment to a volume of $50 \mathrm{~mL}$. The final concentration of each amine was $10 \mu \mathrm{g} \cdot \mathrm{mL}^{-1}$. The $0.1 \mathrm{M}$ $\mathrm{HCl}$ prepared by dissolving $3.5 \mathrm{~mL}$ of $35 \% \mathrm{HCl}$ in deionized water and filled to 1 litre was used as the extraction agent. The derivatizing agent was prepared by dissolving $5 \mathrm{mg}$ of dansyl chloride in $1 \mathrm{~mL}$ of propan-2one.

The following biogenic amines were determined: tyramine, histamine, 2-phenylethylamine, tryptamine, cadaverine, putrescine, spermidine, and spermine. The amine content of each sample was measured in duplicate.

\section{Statistical analysis}

Statistical evaluation was performed in the Statistica Statsoft programme, version 12, and Microsoft Excel 2010. Basic statistical characteristics, such as mean and standard deviation of the mean were calculated.

In order to compare the BA content during the storage period within the given temperature regime, a simple scattering analysis method (ANOVA) including the Duncan post-hoc test was used. Normality was tested by the Shapiro-Wilk test. The proportion of factors (temperature and storage period including interactions) on the total variability of BA content in cheese was calculated using the general linear model (ANOVA with interactions).

\section{RESULTS AND DISCUSSION}

At the beginning of storage $(\mathrm{A} / 0, \mathrm{~B} / 0, \mathrm{C} / 0)$ the total content of the monitored BA was $64.9 \mathrm{mg} \cdot \mathrm{kg}^{-1}$ of cheese (Figure 1). During ripening in storage in the temperature regimes (A) and (C), the total BA content first increased $(p<0.05)$ to $259.7 \mathrm{mg} \cdot \mathrm{kg}^{-1}$. Then it decreased $(p>0.05)$ to $190.4 \mathrm{mg} \cdot \mathrm{kg}^{-1}$ in regime (A) and to $140.7 \mathrm{mg} \cdot \mathrm{kg}^{-1}$ in regime (C). 


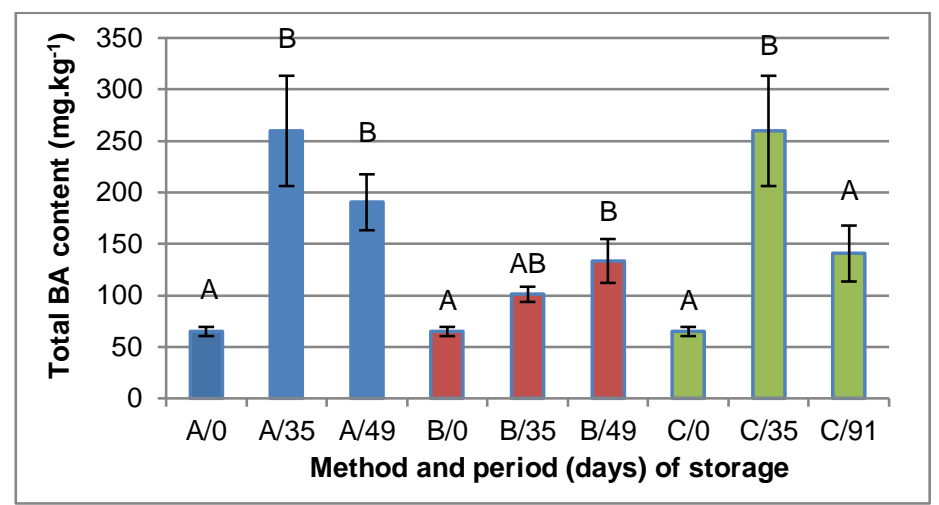

Figure 1 Comparison of the total content of biogenic amines $\left(\mathrm{mg} \cdot \mathrm{kg}^{-1}\right)$ in smear ripened cheeses stored in different temperature regimes (A, B, C) and analysed on the production date (0), at the end of the best before date after 35 days of ripening (A/35: storage at $6{ }^{\circ} \mathrm{C} / 35$ days, $\mathrm{B} / 35$ : Storage at $6{ }^{\circ} \mathrm{C} / 28$ days and at $-18{ }^{\circ} \mathrm{C} / 7$ days, $\mathrm{C} / 35$ : storage at $6{ }^{\circ} \mathrm{C} / 35$ days) and at the end of storage after 49 or 91 days of ripening (A: storage at $6{ }^{\circ} \mathrm{C} / 35$ days and at $6{ }^{\circ} \mathrm{C} / 14$ days, $\mathrm{B}$ : storage at $6{ }^{\circ} \mathrm{C} / 28$ days and at $-18{ }^{\circ} \mathrm{C} / 7$ days and at $6{ }^{\circ} \mathrm{C} / 14$ days, $\mathrm{C}$ : storage at $6{ }^{\circ} \mathrm{C} / 35$ days and at $-18{ }^{\circ} \mathrm{C} / 49$ days and at $6{ }^{\circ} \mathrm{C} / 7$ days). Averages marked with different letters are statistically different within a given factor (storage period) $(p<0.05) ; \mathrm{n}=15$.

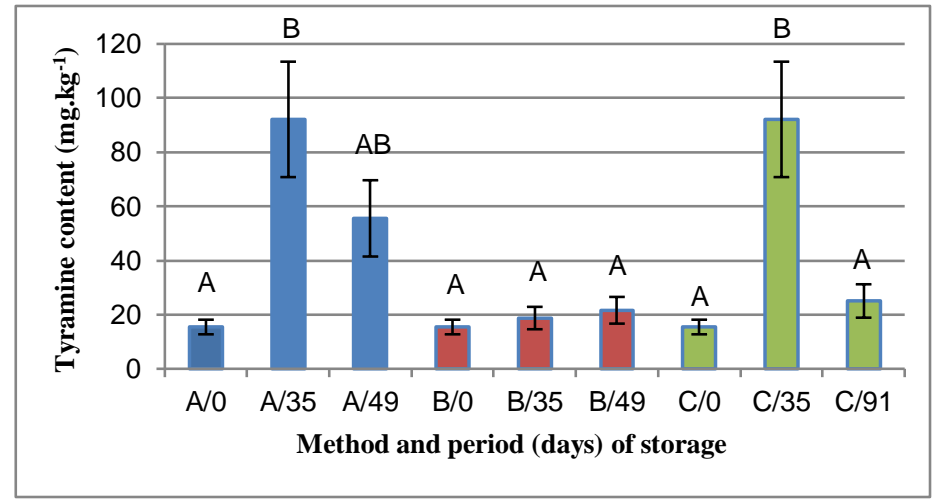

Figure 2 Comparison of tyramine content $\left(\mathrm{mg}_{\mathrm{kg}} \mathrm{kg}^{-1}\right)$ in smear ripened cheeses stored in different temperature regimes $(\mathrm{A}, \mathrm{B}, \mathrm{C})$ and analysed on production day (0), at the end of the best before date after 35 days of ripening (A/35: storage at $6{ }^{\circ} \mathrm{C} / 35$ days, $\mathrm{B} / 35$ : storage at $6{ }^{\circ} \mathrm{C} / 28$ days and at $-18{ }^{\circ} \mathrm{C} / 7$ days, $\mathrm{C} / 35$ : storage at $6{ }^{\circ} \mathrm{C} / 35$ days) and at the end of storage after 49 or 91 days of ripening (A: storage at $6{ }^{\circ} \mathrm{C} / 35$ days and $6{ }^{\circ} \mathrm{C} / 14$ days, B: storage at $6{ }^{\circ} \mathrm{C} / 28$ days and at $-18{ }^{\circ} \mathrm{C} / 7$ days and $6{ }^{\circ} \mathrm{C} / 14$ days, $\mathrm{C}$ : storage at $6{ }^{\circ} \mathrm{C} / 35$ days and at $-18{ }^{\circ} \mathrm{C} / 49$ days and at $6^{\circ} \mathrm{C} / 7$ days). Averages marked with different letters are statistically different within a given factor (storage period) $(p<0.05) ; \mathrm{n}=15$.

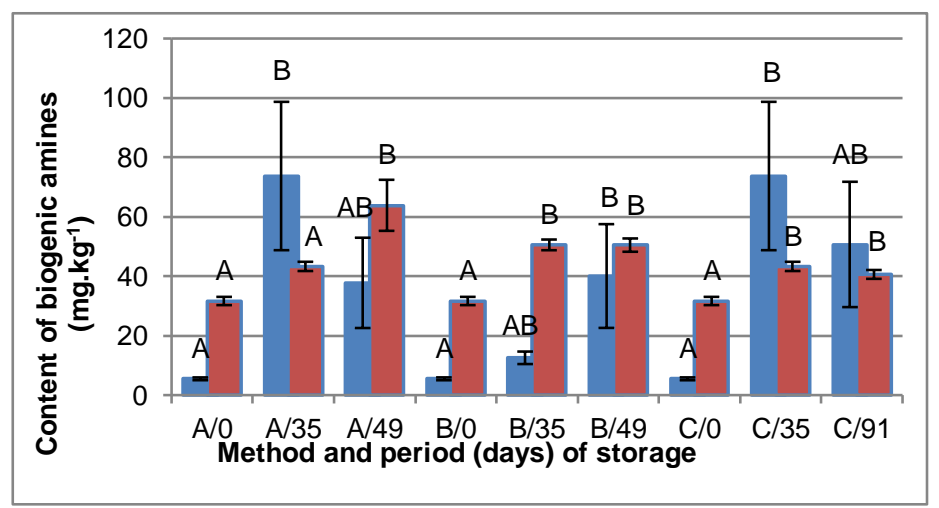

Figure 3 Comparison of putrescine and polyamine content $\left(\mathrm{mg}_{\mathrm{kg}} \mathrm{kg}^{-1}\right.$ ) in smear ripened cheeses stored in different temperature regimes $(\mathrm{A}, \mathrm{B}, \mathrm{C})$ and analysed on production day (0) at the end of the minimum shelf life after 35 days of ripening ( $\mathrm{A} / 35$ : storage at $6{ }^{\circ} \mathrm{C} / 35$ days, $\mathrm{B} / 35$ : storage at $6{ }^{\circ} \mathrm{C} / 28$ days and at $-18{ }^{\circ} \mathrm{C} / 7$ days, $\mathrm{C} / 35$ : storage at $6{ }^{\circ} \mathrm{C} / 35$ days) and at the end of storage after 49 or 91 days of ripening (A: storage at $6{ }^{\circ} \mathrm{C} / 35$ days and $6{ }^{\circ} \mathrm{C} / 14$ days, B: storage at $6{ }^{\circ} \mathrm{C} / 28$ days and at $-18{ }^{\circ} \mathrm{C} / 7$ days and $6{ }^{\circ} \mathrm{C} / 14$ days, $\mathrm{C}$ : storage at $6{ }^{\circ} \mathrm{C} / 35$ days and at $-18^{\circ} \mathrm{C} / 49$ days and $6{ }^{\circ} \mathrm{C} / 7$ days $)$. Averages marked with different letters are statistically different within a given factor (storage period) $(p<0.05)$; $\mathrm{n}=15$. Putrescine is marked blue, polyamines spermidine and spermine red. 
The reduction in the total BA content of cheeses stored in temperature regime (C) was statistically significant ( $p<0.05)$; lower total BA content was recorded at the end of storage $(\mathrm{C} / 91)$ than at the end of BBD (C/35). When stored in regime $(\mathrm{B})$, the total $\mathrm{BA}$ content was higher $(p<0.05)$ at the end of ripening $(\mathrm{B} / 49)$ than on production date $(\mathrm{B} / 0)$. The highest total $\mathrm{BA}$ value was recorded during storage in regime (A) after 35 days of ripening, namely $571.4 \mathrm{mg} \cdot \mathrm{kg}^{-1}$ of cheese.

Higher total BA content compared to ours was detected in smear ripened cheeses by Pleva et al. (2014), namely up to $1,000 \mathrm{mg} \cdot \mathrm{kg}^{-1}$. In 5 samples they show even higher values $\left(1,000-6,000 \mathrm{mg} \cdot \mathrm{kg}^{-1}\right.$ of cheese). They ascribe the increased BA content to incorrect storage of cheese at stores. According to Komprda et al. (2012), the impact of storage temperature on the variability of BA and PA content is $46 \%$ on average. The storage temperature has been reported by Komprda et al. (2012) for BA and PA variability has an average effect of $46 \%$. Higher total BA content, as compared with our data, was also found by Samková, Dadáková and Pelikánová (2013) when cheeses were stored at $5{ }^{\circ} \mathrm{C}$, namely $514 \mathrm{mg} \cdot \mathrm{kg}^{-1}$. After an additional two weeks of storage, the BA content further increased to $660 \mathrm{mg} \cdot \mathrm{kg}^{-1}$, with the highest recorded value of BA being 2,076 mg. $\mathrm{kg}^{-1}$ of cheese. Standarová et al. (2010) for the same type of cheese, and at the same conditions at the end of BBD, detected 1,500 mg. $\mathrm{kg}^{-1} \mathrm{BA}$; Dičáková and Dudriková (2007) 2,477 mg.kg-1; Rejchrtová (2015) $593 \mathrm{mg} \cdot \mathrm{kg}^{-1}$ and 66 days after the production 1,218 mg. $\mathrm{kg}^{-1}$, which are much higher values than our results. According to Standarová et al. (2009), there are also differences in BA content depending on the month of cheese production.

During storage, in temperature regimes (A) and (C) the overall BA content decreased. The reduction in the overall BA content between the $6^{\text {th }}$ and $7^{\text {th }}$ week of storage was reported by Standarová et al. (2010) for cheeses stored at $5{ }^{\circ} \mathrm{C}$. In contrast, no significant changes in the overall BA content of long-frozen $\left(-18{ }^{\circ} \mathrm{C}\right)$ cheeses were found by Andiç et al. (2010), and they explain this finding by slowing down or cessation of microorganism activity. In our experiment, there was apparently for these reasons a reduction $(p<0.05)$ in the overall content of the monitored BAs in regime $(\mathrm{C})$.

Legislative limits on BA content in cheeses are currently not given. Spanier, Bruin and Van Roode (1991) state the content of histamine + tyramine + putrescine + cadaverine to be $900 \mathrm{mg} \cdot \mathrm{kg}^{-1}$ of cheese on maximum. This value was not exceeded in our experiment.

During ripening, 8 biogenic amines were monitored. As for tryptamine, it was not detected in cheese at the beginning of storage at all. Its content was found in cheese only after 35 days of ripening in regimes (A) and (C), averaging $2.7 \mathrm{mg} \cdot \mathrm{kg}^{-1}$. Under conditions of storage regime (B), tryptamine was not detected in cheeses at all. The same results were obtained by Standarová, Borkovcová and Vorlová (2008) when analysing 215 samples of cheeses consumed in the Czech Republic. Tryptamine content in these cheeses was low or tryptamine was not detected at all. Low, up to $5.9 \mathrm{mg} . \mathrm{kg}^{-1}$, or undetectable amounts of tryptamine were also found by Standarová et al. (2009), however in the Niva cheese taken from the Czech distribution network. Samková, Dadáková and
Pelikánová (2013) found at the end of BBD of the same type of cheese tryptamine at $5.3 \mathrm{mg} \cdot \mathrm{kg}^{-1}$, after two more weeks of storage, the content of $5 \mathrm{mg} \cdot \mathrm{kg}^{-1}$, which is more compared to our results. Pleva et al. (2014) just like us did not detect any tryptamine in smear ripened cheeses.

According to Novella-Rodrigues et al. (2003) and Buňková et al. (2010) cadaverine along with tyramine and putrescine belong among the most important BAs in ripened cheeses. As in our experiment, these authors recorded the highest cadaverine values at the end of BBD after 35 days of storage. However, the values we found (26.9 mg. $\mathrm{kg}^{-1}$ ) were more than ten times lower than those of the authors above. Higher cadaverine contents in cheese compared to our results (up to 2,400 mg. $\mathrm{kg}^{-1}$ ) were reported by Pleva et al. (2014) and Standarová et al. (2010) after 28 days of storage at $5{ }^{\circ} \mathrm{C}\left(>400 \mathrm{mg} \cdot \mathrm{kg}^{-1}\right)$. Also, Samková, Dadáková and Pelikánová (2013) report, compared to us, a higher cadaverine content of 176 mg. $\mathrm{kg}^{-1}$ at the end of BBD and $249 \mathrm{mg} \cdot \mathrm{kg}^{-1}$ two weeks after the end of $\mathrm{BB}$ with the same type of cheese.

As for histamine, the highest values in our experiment were detected at the end of BBD during storage at $6{ }^{\circ} \mathrm{C}$, with an average content of $17.5 \mathrm{mg} \cdot \mathrm{kg}^{-1}$ of cheese and the highest recorded value of $49.5 \mathrm{mg} \cdot \mathrm{kg}^{-1}$. Pleva et al. (2014) report higher histamine content $\left(373.8 \mathrm{mg} . \mathrm{kg}^{-1}\right)$ compared to ours for the same type of cheese. Mayer, Fiechter and Fischer (2010), Standarová et al. (2010), and Loizzo et al. (2013) also reported higher histamine content in smear ripened cheeses ranging between $168.3 \mathrm{mg} \cdot \mathrm{kg}^{-1}$ and 500 mg. $\mathrm{kg}^{-1}$. Rejchrtová (2015) also detected higher histamine levels at the end of BBD compared to our results to be 110 mg. $\mathrm{kg}^{-1}$ of cheese and after 66 days of manufacture to be $142 \mathrm{mg} \cdot \mathrm{kg}^{-1}$. Samková, Dadáková and Pelikánová (2013) found at the end of BBD when stored at $5^{\circ} \mathrm{C}$ the histamine content of $51.5 \mathrm{mg} . \mathrm{kg}^{-1}$ of cheese and after two more weeks of storage $55.3 \mathrm{mg} . \mathrm{kg}^{-1}$, which is also higher than our results. Decrease in the histamine content (similar to our experiment) between $30^{\text {th }}$ and $60^{\text {th }}$ day of ripening was reported by Martuscelli et al. (2005) in the Pecorino Abruzzese cheese. Dalgaard et al. (2006) report that short-term freezing had a significant effect on the subsequent decrease in histamine content (in muscle tissue of sea pike). This corresponds to our results when, in regime (B) at the end of $\mathrm{BBD}$, the average histamine content was $8.0 \mathrm{mg} \cdot \mathrm{kg}^{-1}$ of cheese and in regime (A) $17.5 \mathrm{mg} \cdot \mathrm{kg}^{-1}$ of cheese. Standarov, Borkovcová and Vorlová (2008) report that the histamine content of 100 mg. $\mathrm{kg}^{-1}$ of cheese may already induce intoxication in human organisms. However, this level of histamine content was not recorded in our experiment.

Cheeses typically contain up to tens of $\mathrm{mg} \cdot \mathrm{kg}^{-1}$ of 2-phenylethylamine. In our experiment, at the end of BBD in cheeses stored at $6{ }^{\circ} \mathrm{C}$ (regime A), we have detected $5.4 \mathrm{mg} . \mathrm{kg}^{-1}$ of 2-phenylethylamine and two weeks after BBD $1.4 \mathrm{mg} \cdot \mathrm{kg}^{-1}$. Pleva et al. (2014) reported higher content of 2-phenylethylamine in the same type of cheese than in our experiment, namely $11.6 \mathrm{mg} . \mathrm{kg}^{-1}$. In contrast, Samková, Dadáková and Pelikánová, (2013) detected at the end of BBD in smear ripened cheeses a content of 2-phenylethylamine lower than ours, namely $4.3 \mathrm{mg} . \mathrm{kg}^{-1}$. However, after two more weeks of storage compared to our data, the content of 2-phenylethylamine was higher (2.3 mg. $\left.\mathrm{kg}^{-1}\right)$. Standarová, Borkovcová and Vorlová 
(2008) reported that migraine can already be induced by $30 \mathrm{mg} \cdot \mathrm{kg}^{-1}$ of 2-phenylethylamine. This value was not recorded in our experiment.

\section{Tyramine}

At the beginning of storage $(\mathrm{A} / 0, \mathrm{~B} / 0, \mathrm{C} / 0)$, the tyramine content in cheeses was $15.4 \mathrm{mg} \cdot \mathrm{kg}^{-1}$. During the ripening process (Figure 2), in storage in temperature regimes (A) and (C) there was first an increase $(p<0.05)$ of the tyramine content to $92.1 \mathrm{mg} \cdot \mathrm{kg}^{-1}$ of cheese, at the end of BBD after 35 days. At the end of storage in regime (A), lower values were recorded, namely $55.6 \mathrm{mg} \cdot \mathrm{kg}^{-1}$. In regime $(\mathrm{C})$ the decrease $(p<0.05)$ of tyramine content was more pronounced, namely up to $25.1 \mathrm{mg} \cdot \mathrm{kg}^{-1}$ of cheese. During storage in regime (B), the tyramine content did not change in the course of ripening of the cheese $(p>0.05)$. The highest value of tyramine was recorded in our experiment after 35 days of ripening in regime (A), namely $291.7 \mathrm{mg} \cdot \mathrm{kg}^{-1}$ of cheese. The upper limit of tyramine content in food, according to Halász et al. (1994), Shalaby (1996), Silla Santos (1996) and Eerola et al. (1997) ranges from 100 to $800 \mathrm{mg} \cdot \mathrm{kg}^{-1}$ of food. According to Latorre-Moratalla et al. (2008), people taking MAO inhibitors tolerate $50-100 \mathrm{mg}$ tyramine, however problems can even be caused by $6 \mathrm{mg} \cdot \mathrm{kg}^{-1}$ (NovellaRodríguez et al., 2003). In samples stored at $6{ }^{\circ} \mathrm{C}$ (regime A), a "safe limit" of $100 \mathrm{mg} \cdot \mathrm{kg}^{-1}$ was exceeded in 5 out of 15 analysed samples at the end of BBD. Tyramine content $>100 \mathrm{mg} \cdot \mathrm{kg}^{-1}$ was not detected during storage in temperature regime (B) for any cheese.

In the same type of cheese, Standarová et al. (2010) detected the highest tyramine concentration between the $5^{\text {th }}$ and $6^{\text {th }}$ week of storage at $5{ }^{\circ} \mathrm{C}$, which corresponds to our results $(\mathrm{A} / 35)$. Rejchrtová (2015) reported at the end of BBD in the same type of cheese at $5{ }^{\circ} \mathrm{C}$ higher tyramine content compared to ours (>800 mg. $\left.\mathrm{kg}^{-1}\right)$. Samková, Dadáková and Pelikánová (2013) likewise recorded a slightly higher average tyramine values than in our experiment at $5{ }^{\circ} \mathrm{C}$ at the end of $\mathrm{BBD}$, namely $140 \mathrm{mg} \cdot \mathrm{kg}^{-1}$. After two more weeks of storage the value was $163 \mathrm{mg} \cdot \mathrm{kg}^{-1}$, while the highest tyramine reading after extended storage in their experiment was $469 \mathrm{mg} . \mathrm{kg}^{-1}$ of cheese.

In our experiment, the tyramine content as well as histamine and total BA content decreased between the $5^{\text {th }}$ and $7^{\text {th }}$ week of storage (A/49). According to Leuschner et al. (1998), one possible explanation can be the fact that some microorganisms have the ability to degrade tyramine and histamine. In testing 32 strains of $B$. linens and coryneform bacteria, it was found that 21 of them showed histamine or tyramine oxidase activity. These authors further state that Brevibacterium linens (LTH 456 and LTH 3686) were able to reduce the tyramine and histamine content for Munster smear ripened cheese by 55 to $70 \%$. According to Bergey and Holt (1994), Leuschner, Heidel and Hammes (1998) and Dasu et al. (2006), also Pseudomonas sp., Seratia marcescens, Kocuria varians, and other bacteria can decompose the created BA. Komprda et al. (2007) found an increasing content of tyramine with time in a Dutch type cheese from two different manufacturers. Standarová et al. (2009) reported similar results for cheese with blue mould in dough and Martuscelli et al. (2005) for Pecorino Abruzzese cheese.
The latter authors observed the most significant increase in tyramine content between the $14^{\text {th }}$ and $30^{\text {th }}$ day of ripening, which corresponds to our results.

\section{Putrescine}

At the beginning of storage $(\mathrm{A} / 0, \mathrm{~B} / 0, \mathrm{C} / 0)$, the putrescine content in the cheeses was $5.5 \mathrm{mg} \cdot \mathrm{kg}^{-1}$. During ripening (Figure 3), when stored in temperature regime (A) and $(\mathrm{C})$, the content of putrescine in cheeses first increased to $73.7 \mathrm{mg} \cdot \mathrm{kg}^{-1}(p<0.05)$. After expiration of BBD and further storage, putrescine content values in cheeses were lower, namely $37.8 \mathrm{mg} \cdot \mathrm{kg}^{-1}$ in regime (A) and $50.7 \mathrm{mg} \cdot \mathrm{kg}^{-1}$ in regime (C). In temperature regime (B), putrescine content increased $(p<0.05)$ during storage, when after 49 days of storage $(B / 49)$ a higher putrescine content than on production date $(\mathrm{B} / 0)$ was recorded.

Higher content of putrescine, compared to our data, was found by Pleva et al. (2014), when putrescine in smear ripened cheeses was detected at $>2,000$ mg. $\mathrm{kg}^{-1}$. Standarová et al., (2010) also reported that the putrescine content was higher, when after 28 days of ripening at $5{ }^{\circ} \mathrm{C}$ its content was $212 \mathrm{mg} \cdot \mathrm{kg}^{-1}$ in the same type of cheese. In our experiment, too, the highest average putrescine content was found after 35 days of ripening at $6{ }^{\circ} \mathrm{C}$. However, the average content was lower at $73.7 \mathrm{mg} \cdot \mathrm{kg}^{-1}$, while the highest recorded value was $320 \mathrm{mg} \cdot \mathrm{kg}^{-1}$ of cheese. Samková, Dadáková and Pelikánová (2013) detected a higher average putrescine content of $104 \mathrm{mg} \cdot \mathrm{kg}^{-1}$ in smear ripened cheeses at the end of BBD when stored at $5{ }^{\circ} \mathrm{C}$. After two more weeks of storage, the putrescine content increased even more to $137 \mathrm{mg} \cdot \mathrm{kg}^{-1}$.

In our experiment, however, the putrescin content decreased $(p>0.05)$ after a further 2 weeks of storage at $6{ }^{\circ} \mathrm{C}(\mathrm{A} / 49)$. In contrast, in regime (B) the putrescine content of cheeses increased, when at the end of storage $(\mathrm{B} / 49)$ a higher $(p<0.05)$ content of putrescine than at the production date $(B / 0)$ was detected. An increase in the putrescine content during storage (of tuna) at low temperatures $\left(-18{ }^{\circ} \mathrm{C}\right)$ was also reported by Ben-Gigirey et al. (1998). However, during long-term freezing (regime C), there was a decrease in the putrescine content in cheeses, which is probably related to the decrease of enzymatic activity of microorganisms (Andiç et al., 2010).

\section{Polyamines}

As regards PAs (spermidine and spermine), their content in cheeses was $31.7 \mathrm{mg} \cdot \mathrm{kg}^{-1}$ at the beginning of storage $(\mathrm{A} / 0, \mathrm{~B} / 0, \mathrm{C} / 0)$. During storage, the PA $(p<0.05)$ content has increased in all temperature regimes. At the end of the storage period, the cheeses had a higher $(p<0.05)$ PA content than on the day of production (Figure 3 ).

At present, PAs and their precursor putrescine are classified differently from the BA group. PAs may originate in a different metabolic pathway and are characterized by different biological functions. Pleva et al. (2014) show higher PA values compared to ours (A/35) for the same type of cheese, namely $55.8 \mathrm{mg} \cdot \mathrm{kg}^{-1}$ on average. In contrast, Samková, Dadáková and Pelikánová (2013) measured lower values of PAs at the end of BBD compared to ours, namely $33 \mathrm{mg} \cdot \mathrm{kg}^{-1}$ for cheeses stored at $5{ }^{\circ} \mathrm{C}$. After two more weeks of storage, they found a PA 
content of $48.2 \mathrm{mg} \cdot \mathrm{kg}^{-1}$ of cheese, which is also less compared to our values (A/49).

\section{CONCLUSION}

Our hypothesis regarding the effect of temperature on BA formation in cheeses was confirmed. Their content was higher at $6{ }^{\circ} \mathrm{C}$ than when stored at freezing temperatures. Freezing does not completely deactivate the enzymes, as enzyme reactions are slowly taking place even at freezing temperatures. However, it is important to keep in mind that low temperatures recommended for food storage were used in our experiment.

The highest $(p<0.05)$ total BA content was found when storing the cheeses at the end of BBD (best before date) after 35 days (259.7 mg. $\mathrm{kg}^{-1}$ ) in storage regime (A) or (C). During storage in regime (B), the total BA content $(p<0.05)$ after 49 days of storage was higher than on the production date $(\mathrm{B} / 0)$. During storage, the tyramine content in regime $(\mathrm{B})$ did not change $(p>0.05)$, while in the temperature regimes $(\mathrm{A})$ and $(\mathrm{C})$, the highest levels of tyramine and putrescine content were recorded in cheeses at the end of BBD after 35 days ripening (92.1 mg. $\mathrm{kg}^{-1}$, resp. $\left.73.7 \mathrm{mg} \cdot \mathrm{kg}^{-1}\right)$. The content of polyamines in cheeses was higher $(p<0.05)$ at the end of storage: $63.9 \mathrm{mg} \cdot \mathrm{kg}^{-1}$ in storage regime (A), resp. $50.5 \mathrm{mg} \cdot \mathrm{kg}^{-1}$ in storage regime (B) and $40.6 \mathrm{mg} \cdot \mathrm{kg}^{-1}$ in storage regime (C), than at the beginning (31.7 mg. $\left.\mathrm{kg}^{-1}\right)$.

Analyses performed (ANOVA with interactions) show that greater effect on the content of BAs (tyramine, putrescine) and PAs had the period of storage rather than the method of storage (temperature regime).

\section{REFERENCES}

Andiç, S., Gençcelep, H., Tunçtürk, Y., Köse, Ş. 2010. The effect of storage temperatures and packaging methods on properties of Motal cheese. Journal of Dairy Science, vol. 93, no. 3, p. 849-859. https://doi.org/10.3168/jds.2009-2413

Ben-Gigirey, B., De Sousa, J. M. V. B., Villa, T. G., BarrosVelazquez, J. 1998. Changes in biogenic amines and microbiological analysis in albacore (Thunnus alalunga) muscle during frozen storage. Journal of Food Protection, vol. 61 , no. 5, p. 608-615. https://doi.org/10.4315/0362-028X$\underline{61.5 .608}$

Bergey, D. H., Holt, J. G. 1994. Bergey's manual of determinative bacteriology. $9^{\text {th }}$ ed. Baltimore, USA : Williams \& Wilkins, 754 p. ISBN 978-0-68300603-2.

Buňková, L., Buňka, F., Mantlová, G., Čablová, A., Sedláček, I., Švec, P., Pachlová, V., Kráčmár, S. 2010. The effect of ripening and storage conditions on the distribution of tyramine, putrescine and kadaverine in Edam cheese. Food Microbiology, vol. $\quad 27, \quad$ p. $\quad 880-888$. https://doi.org/10.1016/j.fm.2010.04.014

Dalgaard, P., Madsen, H. L., Samieian, N., Emborg, J. 2006. Biogenic amine formation and microbial spoilage in chilled garfish (Belone belone belone) - effect of modified atmosphere packaging and previous frozen storage. Journal of Applied Microbiology, vol. 101, no. 1, p. 80-95. https://doi.org/10.1111/j.1365-2672.2006.02905.x

Dasu, V. V., Nakada, Y., Ohnishi-Kameyama, M., Kimura, K., Itoh, Y. 2006. Characterization and role of Pseudomonas aeruginosa spermidin dehydrogenase in polyamine catabolism. Microbiology, vol. 152, no. 8, p. 2265-2272. https://doi.org/10.1099/mic.0.28920-0
Dičáková, Z., Dudriková, E. 2007. Is it direct correlation between putrefaction factors and putrescine presence in cheese? In Proc. Hygiena Alimentorum XXVIII: "Safety and Quality of Milk and Milk Products". Štrbské Pleso,Vysoké Tatry, Slovakia : University of Veterinary Medicine and Pharmacy in Košice, p. 138-148.

Eerola, S., Sagués, A. X. R., Lilleberg, L., Aalto, H. 1997. Biogenic amines in dry sausages during shelf-life storage. Zeitschrift für Lebensmitteluntersuchung und-Forschung A, vol. 205, p. 351-355. https://doi.org/10.1007/s002170050179

Halász, A., Baráth, A., Sarkadi, L. S., Holzapfel, W. 1994. Biogenic amines and their production by microorganism in food. Trends in Food Science \& Technology, vol. 5, no. 2, p. 42-49. https://doi.org/10.1016/0924-2244(94)90070-1

Komprda, T., Rejchrtová, E., Sládková, P., Zemánek, L., Vymlátilová, L. 2012. Effect of some external factors on the content of biogenic amines and polyamines in a smear ripened cheese. Dairy Science \& Technology, vol. 92, no. 4, p. 367-382. https://doi.org/10.1007/s13594-012-0075-4

Komprda, T., Smělá, D., Novická, K., Kalhotka, L., Šustová, K., Pechová, P. 2007. Content and distribution of biogenic amines in Dutch type hard cheese. Food Chemistry, vol. $102, \quad$ p. $129-137$. https://doi.org/10.1016/j.foodchem.2006.04.041

Latorre-Moratalla, M. L., Veciana-Nogués, T., Bover-Cid, S., Garriga, M., Aymerich, T., Zanardi, E., Ianieri, A., Fraqueza, M. J., Patarata, L., Drosinos, E. H., Lauková, A., Talon, R., Vidal-Carou, M. C. 2008. Biogenic amines in traditional fermented sausages produced in selected European countries. Food Chemistry, vol. 107, p. 912-921. https://doi.org/10.1016/j.foodchem.2007.08.046

Leuschner, R., Heidel, G., Hammes, W. P. 1998. Histamine and tyramine degradation by food fermenting microorganisms. International Journal of Food Microbiology, vol. 39, no. 1-2, p. 1-10. https://doi.org/10.1016/S0168$\underline{1605(97) 00109-8}$

Loizzo, M. R., Menichini, F., Picci, N., Puoci, F., Spizzirri, G., Restuccia, D. 2013. Technological aspects and analytical determination of biogenic amines in cheese. Trends in Food Science \& Technology, vol. 30, no. 1, p. 38-55. https://doi.org/10.1016/j.tifs.2012.11.005

Madejska, A., Michalski, M., Osek, J. 2017. Biogenic amines in rennet ripening cheeses as a health risk to consumers. Medycyna Weterynaryjna-Veterinary MedicineScience and Practice, vol. 73, no. 4, p. 214-219. https://doi.org/10.21521/mw.5681

Martuscelli, M., Gardini, F., Torriani, S., Mastrocola, D., Serio, A., Chavez-López, C., Schirone, M., Suzzi, G. 2005. Production of biogenic amines during the ripening of Pecorino Abruzzese cheese. International Dairy Journal, vol. 15, no. 6, p. 571-578. https://doi.org/10.1016/j.idairyj.2004.11.008

Mayer, H. K., Fiechter, G., Fischer, E. 2010. A new ultra pressure liquid chromatography method for the determination of biogenic amines in cheese. Journal of Chromatography A, vol. 1217, no. 19, p. 3251-3257. https://doi.org/10.1016/j.chroma.2009.09.027

Novella-Rodríguez, S., Veciana, M. T., Izquierdo-Pulido, M., Vidal-Carou, M. C. 2003. Distribution of biogenic amines and polyamines in cheese. Journal of Food Science, vol. 68, no. 3 , p. 750-755. https://doi.org/10.1111/j.13652621.2003.tb08236.x

Novella-Rodríguez, S., Veciana-Nogués, M. T., RoigSagués, A. X., Truillo-Mesa, A. J., Vidal-Carou, M. C. 2004. Evaluation of biogenic amines and microbial counts throughout the ripening of goat cheeses from pasteurized and 
raw milk. Journal of Dairy Research, vol. 71, no. 2, p. 245-252. https://doi.org/10.1017/S0022029904000147

Önal, A., Tekkeli, S. E. K., Önal, C. 2013. A review of the liquid chromatographic methods for the determination of biogenic amines in foods. Food Chemistry, vol. 138, no. 1, p. 509-515. https://doi.org/10.1016/j.foodchem.2012.10.056

Pinho, O., Pintado, A. I. E., Gomes, A. M. P., Pintado, M. M. E., Malcata, F. X., Ferreira, I. M. P. L. V. O. 2004. Interrelationships among microbiological, physicochemical, and biochemical properties of Terrincho cheese, with emphasis on biogenic amines. Journal of Food Protection, vol. 67 , no. 12 , p. 2779-2785. https://doi.org/10.4315/0362028X-67.12.2779

Pleva, P., Buňková, L., Theimrová, E., Bartošáková, V., Buňka, F., Purevdorj, K. 2014. Biogenic amines in smear and mould-ripened cheeses. Potravinarstvo, vol. 8, no. 1, p. 321-327. https://doi.org/10.5219/408

Poveda, J. M., Molina, G. M., Gómez-Alonso, S. 2016. Variability of biogenic amine and free amino acid concentrations in regionally produced goat milk cheeses. Journal of Food Composition and Analysis, vol. 51, no. C, 85-92. https://doi.org/10.1016/j.jfca.2016.06.012

Rejchrtová, E. 2015. Microorganisms with decarboxylasis activity in some fermented food : dissertation theses. Brno, Czech Republic : Mendel university in Brno, $87 \mathrm{p}$.

Samková, E., Dadáková, E., Pelikánová, T. 2013. Changes in biogenic amine and polyamine contents in smear-ripened cheeses during storage. European Food Research and Technology, vol. 237, no. 3, p. 309-314. https://doi.org/10.1007/s00217-013-1993-y

Shalaby, A. R. 1996. Significance of biogenic amines to food safety and human health. Food Research International, vol. 29 , no. 7, p. 675-690. https://doi.org/10.1016/S09639969(96)00066-X

Silla Santos, M. H. 1996. Biogenic amines: their importance in foods. International Journal of Food Microbiology, vol. 29 , no. 2-3, p. 213-231. https://doi.org/10.1016/0168$\underline{1605(95) 00032-1}$
Spanier, M. C., Bruin, T. J. F., Van Roode, B. A. S. W. 1991. HPLC determination of biogenic amines and evaluation of results. In Deelstra, H. Food Policy Trends in Europe Nutrition technology, analysis and safety. The Netherlands : Springer Netherlands, 213 p. ISBN 978-0-7476-0075-6.

Standarová, E., Borkovcová, I., Dušková, M., Přidalová, H., Dračková, M., Vorlová, L. 2009. Effect of some factors on the biogenic amines and polyamines content in Blue-Veined cheese Niva. Czech Journal of Food Science, vol. 27, no. Special Issue, p. 410-413. https://doi.org/10.17221/965-CJFS

Standarová, E., Borkovcová, I., Vorlová, L. 2008. Obsah biogenních aminů $\mathrm{v}$ sýrech $\mathrm{z}$ české obchodní sítě. Veterinářství, vol. 58, p. 735-739.

Standarová, E., Vorlová, L., Kordiovská, P., Janštová, B., Dračková, M., Borkovcová, I. 2010. Biogenic amine production in Olomouc curd cheese (Olomoucke tvaruzky) at various storage conditions. Acta Veterinaria Brno, vol. 79, no. 1, p. 147-156. https://doi.org/10.2754/avb201079010147

Torracca, B., Pedonese, F., López, M. B., Turchi, B., Fratini, F., Nuvoloni, R. 2016. Effect of milk pasteurisation and of ripening in a cave on biogenic amine content and sensory properties of a pecorino cheese. International Dairy Journal, vol. 61, p. https://doi.org/10.1016/j.idairyj.2016.05.007

\section{Contact address:}

*MVDr. Olga Cwiková, Ph.D., Mendel University in Brno, Faculty of AgriSciences, Department of Food Technology, Zemědělská 1, 61300 Brno, Czech Republic, Tel.: +545133339,

E-mail: cwikova@mendelu.cz

Ing. Gabriela Franke, Ph.D., Mendel University in Brno, Faculty of AgriSciences, Department of Food Technology, Zemědělská 1, 61300 Brno, Czech Republic, Tel.: +545133339,

E-mail: G.Zornikova@email.cz

Corresponding author: * 